\title{
The Influence of Entrepreneurial Characteristics of Arabica Coffee to Business Performance Farmer's In Karo Regency
}

\section{Pengaruh Karakteristik Wirausaha Terhadap Kinerja Usahatani Kopi Arabika Di Kabupaten Karo}

\author{
Elvin Desi Martauli ${ }^{1}{ }^{1}$ Lasma Melinda Siahaan ${ }^{2)}$ \\ ${ }^{1)}$ Dosen Prodi Agribisnis, Universitas Quality Berastagi, Indonesia \\ Jl. LauGumba Peceren Berastagi, Kabupaten Karo \\ ${ }^{2)}$ Dosen Prodi Ekonomi Pembangunan, Universitas Quality, Indonesia \\ Jl. Ngumban Surbakti No.18, Kota Medan \\ Email : elvindesi@ymail.com
}

\begin{abstract}
Coffee farming opportunities, if well developed, will have an impact on increasing business performance. One of the efforts that can be done is building quality human resources based on entrepreneurial characteristics. Entrepreneurial characteristics are thought to have a significant influence on the occurrence of farm performance improvement. The purpose of this study was to analyze the characteristics of entrepreneurship, the performance of coffee farming and analyze the effect of entrepreneurial characteristics on the performance of Arabica coffee farming in Karo Regency Respondents used as the sample of this study were taken using cluster random sampling techniques from three districts with a total of 120 respondents of Arabica coffee farmers. The analytical tool used in this research is descriptive analysis and Partial Least Square (SEM-PLS). The results of research on farm performance variables are significant and positive influenced by the characteristics of entrepreneurship. Variable characteristics that have a positive effect are experience, desire to do business, perception and courage to take risks. The most dominant characteristic of entrepreneurship is the desire to do business, but overall it can be said to be strong.
\end{abstract}

Keywords: Entrepreneurial Characteristics, Farming Performance, Arabica Coffee

\begin{abstract}
Abstrak
Peluang usahatani kopi jika dikembangkan dengan baik, maka akan berdampak terhadap meningkat kinerja usahanya. Upaya yang dapat dilakukan salah satunya yaitu dengan membangun sumberdaya manusia yang berkualitas berdasarkan karakteristik wirausaha. Karakteristik wirausaha diduga memiliki pengaruh yang signifikan terhadap terjadinya peningkatan kinerja usahatani. Tujuan penelitian ini adalah untuk menganalisis karakteristik wirausaha, kinerja usahatani kopi dan menganalisis pengaruh dari karakteristik wirausaha terhadap kinerja usahatani kopi arabika di Kabupaten Karo. Responden yang dijadikan sampel penelitian ini diambil dengan menggunakan teknik cluster random sampling dari tiga kecamatan dengan total responden sebanyak 120 orang petani kopi arabika. Alat analisis yang digunakan dalam penelitian ini adalah adalah analisis deskriptif dan Partial Least Square (SEMPLS). Hasil penelitian variabel kinerja usahatani siginifikan dan positif di pengaruhi oleh karakteristik wirausaha. Variable karakteristik yang berpengaruh positif yaitu pengalaman, keinginan berusahatani, persepsi dan keberanian mengambil risiko. Karakteristik wirausaha yang paling dominan yaitu keinginan berusahatani, akan tetapi secara keseluruhan dapat dikatakan kuat.
\end{abstract}

Kata Kunci : Karakteristik Wirausaha, Kinerja Usahatani, Kopi Arabika

\section{A. PENDAHULUAN}

Kopi (Coffea sp.) merupakan salah satu komoditas perdagangan terpenting di dunia dan banyak dibudidaya oleh negara-negara salah satunya yaitu Indonesia (Kanaka dan Chinadurai, 2012; Meiri et al, 2013). Indonesia merupakan produsen kopi terbesar keempat dunia setelah Brazil, Vietnam, dan
Kolombia pada tahun 2015-2016. Volume produksi kopi Indonesia mencapai 739 ribu ton. Produksi kopi Brazil merupakan yang tertinggi mencapai lebih dari 3 juta ton dan Vietnam sebesar 1,7 juta ton. Kolombia berada pada posisi ketiga dengan produksi 840 ribu ton (ICO, 2019). 
Produksi kopi arabika di Indonesia mencapai rata-rata 160,86 ribu ton periode 2013 hingga 2017 atau berkontribusi hanya $18,13 \%$ terhadap total produksi kopi Indonesia yang rata-rata mencapai 647,20 ribu ton kopi berasan (Martauli, 2018). Data AEKI (2019) menunjukkan bahwa provinsi yang menjadi sentra produksi kopi di Indonesia yaitu Sumatera Utara, Bengkulu, Sumatera Selatan,
Lampung, dan Jawa Timur. Perkembangan volume dan nilai ekspor kopi dari tahun 2012-2016 berfluktuasi. Volume ekspor jenis kopi Arabika tertinggi yaitu pada tahun 2015 sebesar 70.784.579 $\mathrm{kg}$ kemudian pada tahun 2016 mengalami penurunan yaitu sebesar 19,66\% (Tabel 1).

Tabel 1. Perkembangan Volume dan Nilai Ekspor Kopi Tahun 2012-2016

\begin{tabular}{|c|c|c|c|c|}
\hline \multirow{2}{*}{ Tahun } & \multicolumn{4}{|c|}{ Jenis Kopi } \\
\cline { 2 - 5 } & \multicolumn{2}{|c|}{ Arabika } & Rolume $(\mathrm{kg})$ & Nilai (USD) \\
\cline { 2 - 5 } & Volume (kg) & Nilai (USD) & 2.941 .274 & 6.634 .023 \\
\hline 2012 & 61.489 .167 & 364.979 .728 & 1.616 .163 & 3.531 .223 \\
\hline 2013 & 61.740 .606 & 250.826 .258 & 584.480 & 1.457 .312 \\
\hline 2014 & 65.277 .533 & 348.391 .646 & 144.570 & 296.029 \\
\hline 2015 & 70.784 .579 & 363.265 .263 & 156.600 & 382.464 \\
\hline 2016 & 63.448 .254 & 300.828 .415 & & \\
\hline
\end{tabular}

Sumber: AEKI, 2019

Kabupaten Karo merupakan salah salah satu daerah penghasil kopi arabika di Provinsi Sumatera Utara. Hal ini dikarenakan topologi wilayahnya yang sangat cocok untuk kesuburan tanaman kopi. Produksi kopi di Kabupaten Karo pada tahun 2016 memberikan kontribusi sebesar 13,96\% dari 50.405 ton produksi kopi di Sumatera Utara (Kementerian Pertanian, 2016). Kopi juga menjadi salah satu komoditas yang diminati oleh petani di Kabupaten Karo dan berperan sebagai sumber pendapatan utama atau tambahan bagi masyarakat petani.

Mayoritas petani menjalankan kegiatan pertanian di daerah pedesaan. Umumnya, kegiatan usahatani yang dilakukan masih skala kecil atau disebut dengan usaha perkebunan rakyat. Hal ini dikarenakan, usaha yang dijalankan masih terbatas pada akses modal, teknologi yang digunakan masih sederhana serta informasi yang masih terbatas. Selain itu, terdapat faktor lain yang dianggap penting seperti entrepreneur skill petani yang masih rendah, dikarenakan usahatani yang dijalankan belum menuju ke arah pengembangan bisnis.

Kewirausahaan berkualitas jika diikuti dengan kesadaran dari petani untuk meningkatkan kemampuan diri dalam bidang usaha yang dijalankan. Peningkatan jumlah wirausaha diharapkan akan sejalan dengan berkualitas dan semakin baik dan akan memberikan dampak terhadap semakin memakmurkan rakyatnya. Pertumbuhan wirausaha diarahkan pada jumlah peningkatan wirausaha petani yang akan menjadi basis perekonomian bagi masyarakat.

Peningkatan wirausaha akan berpengaruh terhadap kesejahteraan masyarakat. Hal ini dikarenakan (a) agribisnis tropis dalam produksi, artinya sumber daya lokal yang ada dalam jumlah banyak dari yang tersedia, (b) banyaknya tenaga kerja yang dibutuhkan berdasarkan jenis strata, (c) produk dan jasa yang dihasilkan harus dibutuhkan oleh pasar. Menurut Minniti dan Bygrave (2001), penelitian tentang karakteristik wirausaha pada petani belum banyak dilakukan. Terdapat banyak faktor yang mempengaruhi pembelajaran kewirausahaan. Faktor-faktor pembentuk seperti pengalaman, pelatihan, pendidikan, monitoring. Pada dasarnya petani telah dianggap sebagai seorang wirausaha melalui proses pembelajaran yang dilakukan selama menjalankan kegiatan usahatani. Proses pembelajaran yang diperoleh petani seperti berani dalam mengambil risiko, keputusan berusahatani, adopsi terhadap suatu teknologi baru, inovasi dan lain sebagainya. Menjadi petani wirausaha pada sektor agribisnis belum didukung faktor pendukung. Hal ini dikarenakan masih terbatasnya dan keterbelakangan petani. Berdasarkan pendahuluan yang diuraikan, maka perumusan masalah ini adalah (1) bagaimana karakteristik responden petani kopi arabika di Kabupaten Karo; (2) bagaimana pengaruh karakteristik wirausaha petani kopi arabika terhadap kinerja usahatani di Kabupaten Karo.

\section{METODE PENELITIAN}

Lokasi penelitian ini dilakukan di tiga kecamatan di Kabupaten Karo yaitu Kecamatan Barusajahe, Tigapanah, Merek. Pemilihan lokasi dilakukan dengan sengaja (purposive location) dengan pertimbangan bahwa Kabupaten Karo merupakan salah satu daerah penghasil kopi arabika 
di Provinsi Sumatera Utara, sedangkan tiga kecamatan tersebut adalah sentra produksi kopi arabika di Kabupaten Karo.

Data yang dikumpulkan pada penelitian ini adalah data primer dan data sekunder. Data primer diperoleh diperoleh dari wawancara langsung dengan petani kopi arabika dengan menggunakan daftar pernyataan (kuesioner) yang telah disiapkan. Data sekunder diperoleh dari BPS kabupaten dan BPS Provinsi Sumatera Utara, Dinas Pertanian Kabupaten Karo.

Penentuan responden dilakukan dengan teknik Cluster Random Sampling secara proporsional berdasarkan kecamatan dengan petani kopi arabika. Kecamatan tersebut terdiri dari Kecamatan Tigapanah, Barusjahe, Merek. Jumlah responden yang diambil berjumlah 120 orang petani kopi arabika.

Pengolahan data dilakukan secara kualitatif dan kuantitatif. Analisis kualitatif menggunakan metode deskriptif melalui pembuatan tabulasi frekuensi sederhana berdasarkan jawaban responden yang kemudian ditabulasi dan dipersentasekan. Pengolahan data dilakukan dengan menggunakan alat bantu software komputer Microsoft Excel 2013 untuk tabulasi data, dan SPSS versi 16 untuk uji validitas dan uji reliabilitas kuesioner yang digunakan. Analisis kuantitatif untuk melihat pegaruh karakteristik wirausaha terhadap kinerja usaha dilakukan menggunakan program software SmartPLS 3.0 untuk analisis Partial Least Square.
Partial Least Square merupakan metode analisis yang powerful karena dapat diterapkan pada semua skala data, tidak membutuhkan banyak asumsi dan ukuran sampel tidak harus besar. Menurut Wold (1982) dalam Ghozali (2008) data pada analisis partial Least Square tidak harus berdistribusi normal multivariate atau indikator dengan skala kategori, ordinal, interval, sampai ratio dapat digunakan pada model yang sama. SEM-PLS juga dapat digunakan untuk menjelaskan ada tidaknya pengaruh antar variabel. Partial Least Square juga dikembangkan untuk perancangan model statistik yang mempunyai model lemah atau indikator yang tersedia memenuhi model pengukuran refleksif dan formatif. Setelah memenuhi salah satu model pengukuran maka data dapat diestimasi, estimasi parameter yang didapat dengan PLS dapat dikategorikan menjadi tiga yaitu Weight estimate, path estimate, dan berkaitan dengan means dan lokasi parameter (nilai konstanta regresi) untuk indikator dan variabel laten. Didalam estimasi juga terdapat blok-blok yang memisahkan variabel laten dan indikator-indikatornya.

Variabel-variabel yang digunakan dalam penelitian ini terdiri dari variabel laten dan variabel manifest sebagai indikator dari variabel laten. Pengukuran peubah variabel-variabel didasarkan pada konsep yang telah terbukti secara empiris, sehingga dapat di implementasikan di lapangan serta mampu diukur sebagaimana seharusnya (tabel 2).

Tabel 2. Variabel indikator karakteristik wirausaha

\begin{tabular}{|c|c|c|c|}
\hline $\begin{array}{l}\text { Variabel Laten } \\
\text { (Latent variable) }\end{array}$ & $\begin{array}{l}\text { Variabel Manifest } \\
\text { (Manifest variable) }\end{array}$ & Simbol & Penjelasan (Explanation) \\
\hline Karakteristik & Pengalaman & KWR.1 & Lamanya berusahatani \\
\hline \multirow[t]{4}{*}{ Wirausaha (KWR) } & Pendidikan & KWR.2 & Pendidikan adalah tingkat pendidikan formal \\
\hline & Persepsi terhadap usahatani & KWR.3 & Pandangan petani terhadap usaha kopi \\
\hline & $\begin{array}{l}\text { Keberanian mengambil } \\
\text { risiko }\end{array}$ & KWR.4 & $\begin{array}{l}\text { Keberanian menghadapi risiko dalam } \\
\text { menjalankan usaha, }\end{array}$ \\
\hline & Keinginan Berusahatani & KW.5 & Keinginan untuk berusahatani \\
\hline \multirow[t]{3}{*}{$\begin{array}{l}\text { Kinerja Usahatani } \\
(\mathrm{KU})\end{array}$} & Perluasan wilayah pasar & KU.1 & $\begin{array}{l}\text { Wilayah pemasaran yang semakin luas dari } \\
\text { periode sebelumnya }\end{array}$ \\
\hline & Peningkatan Pendapatan & KU.2 & $\begin{array}{l}\text { Pendapatan yang meningkat dari periode } \\
\text { sebelumnya }\end{array}$ \\
\hline & Komitmen berusahatani & KU.3 & $\begin{array}{l}\text { Sejauhmana keinginan petani untuk menjalani } \\
\text { dan mempertahankan usaha }\end{array}$ \\
\hline
\end{tabular}

Ghozali (2008) menyatakan bahwa tujuan PLS adalah membantu peneliti untuk tujuan prediksi. Model Path Modelling Partial Least Square pada penelitian ini dapat dilihat pada Gambar 1. 


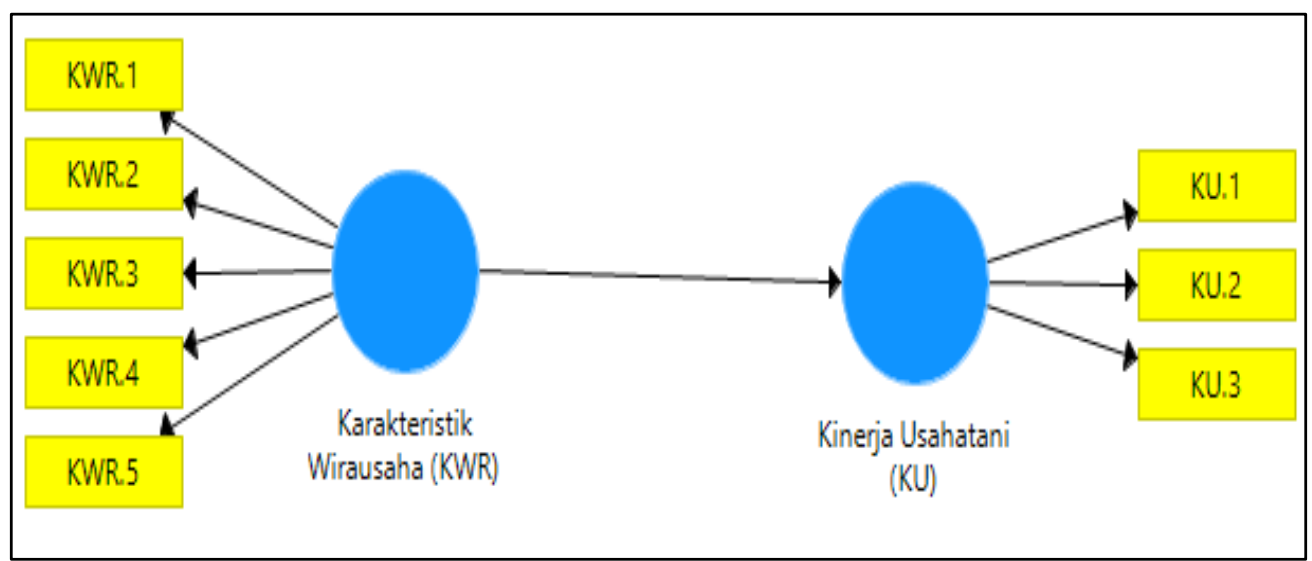

Gambar 1. Model Partial Leasat Square (SEM-PLS) Karateristik Wirausaha

\section{HASIL DAN PEMBAHASAN} Karakteristik Petani Responden

Sebagian besar usahatani kopi berdasarkan jenis kelamin didominasi oleh pria mencapai $84,17 \%$, wanita $15,83 \%$. Usia responden kisaran $41-45$ tahun berada pada usia produktif mencapai $69,17 \%$ dan $14,17 \%$ pada kisaran usia 25-40 tahun, dikarenakan kalangan milenial masih kurang berminat untuk menjadi seorang petani. Dari data karakteristik responden menunjukkan bahwa usahatani di Kabupaten Karo merupakan mata pencaharian yang masih disukai pada usia 41-45 tahun. Pendidikan formal petani sebagai besar merupakan lulusan SMU mencapai $64,17 \%$ dan SMP sebesar $21,67 \%$. Secara umum, melalui data tersebut dapat disimpulkan bahwa sektor pertanian dinilai kurang dapat memberikan insentif dibanding sektor lain untuk tenaga kerja yang berpendidikan tinggi, meskipun ada dalam usia produktif. Rendahnya tingkat pendidikan petani dikhawatirkan akan makin menurunkan kualitas di sektor pertanian karena akan berimbas pada kemampuan untuk merespon tuntutan kebutuhan dan preferensi pasar. Sementara itu di sisi lain pendidikan berpengaruh positif terhadap pertumbuhan ekonomi, karena menjadi sarana untuk meningkatkan kualitas sumber daya manusia yang nantinya menghasilkan tenaga kerja yang lebih produktif (Purnami \& Saskara 2016).

Tabel 3. Karakteristik petani kopi arabika di Kabupaten Karo

\begin{tabular}{lll}
\hline Karakteristik Responden & Jumlah & Persentase (\%) \\
\hline Jenis Kelamin & 101 & 84,17 \\
Laki-laki & 19 & 15,83 \\
Perempuan & & \\
Usia & 5 & 4,17 \\
$<25$ tahun & 17 & 14,17 \\
25-40 tahun & 83 & 69,17 \\
41-45 tahun & 15 & 12,50 \\
>55 tahun & & \\
Pendidikan Formal & 5 & 4,17 \\
Tidak sekolah & 10 & 8,33 \\
Lulus SD & 26 & 21,67 \\
Lulus SMP & 77 & 64,17 \\
Lulus SMA & 2 & 1,67 \\
Lulus D1/D3/S1 & & \\
Luas Lahan & 85 & 70,83 \\
Sempit: 0.5-1.5 ha & 35 & 29,17 \\
Luas: > 1.5 ha & & \\
Pengalaman & 18 & 15 \\
<5 Tahun & 87 & 72,50 \\
5-10 Tahun & 5 & 4,17 \\
11-15 Tahun & 10 & 8,33 \\
$>15$ Tahun & & \\
\hline
\end{tabular}




\begin{tabular}{lll}
\hline $\begin{array}{l}\text { Kepemilikan Lahan Kopi } \\
\text { Pribadi }\end{array}$ & 120 & 100 \\
Pendapatan Petani Kopi & & \\
< Rp 1.000.000 & 20 & 16,67 \\
Rp 1.000.000 - Rp 2.000.000 & 25 & 20,83 \\
Rp 2.100.000 - Rp 3.000.000 & 65 & 54,17 \\
Rp 3.100.000 - Rp 4.000.000 & 10 & 8,33 \\
\hline
\end{tabular}

Tabel 3, menunjukkan bahwa luas lahan usahatani kopi di Kabupaten Karo sebagian besar petani memiliki luas lahan sempit sebesar 70,83\% dan luas lahan $>1,5$ ha sebesar $29,17 \%$. Untuk pengalaman petani responden yaitu 5-10 Tahun mencapai $72,50 \%$. Hal ini menunjukkan bahwa petani kopi arabika di Kabupaten Karo sudah cukup berpengalaman dalam menjalankan usahatani kopi. Hasil penelitian Puspitasari (2013) pengalaman petani yang cukup berpeluang dalam pengembangan usaha agar keberhasilan dapat tercapai. Petani dengan pengalaman yang rendah adalah petani baru dengan pengalaman rendah dan kurang tertarik menjalankan usahatani.

Tabel 3 menunjukkan bahwa pendapatan petani kopi yaitu Rp 2.100.000-Rp 3.000.000 sebesar $54,17 \%$, selanjutnya tingkat pendapatan Rp 1.000.000-Rp 2.000.000 perbulan sebesar 20,83\%. Sebagian besar petani responden mengakui bahwa

usaha yang dijalankan merupakan sumber usaha sampingan keluarga, karena petani responden memiliki mata pencaharian lain seperti sebagai petani sayur. Menurut Walter dan Smallbone (2011) bahwa suatu usaha dikatakan diversifikasi berupa kegiatan tambahan jasa atau perdagangan. Kegiatan tambahan memberikan kontribusi pada usaha bisnis utama untuk dapat mengakses modal eksternal yang langka. Sebagian petani kopi arabika mempunyai pekerjaan sampingan selain menjadi seorang petani kopi juga menjadi petani sayur-mayur.

Hasil evaluasi model pengukuran tahap awal, pada model pengaruh karakteristik wirausaha yang dikembangkan pada penelitian ini dapat dilihat pada Gambar 2. Hasil evaluasi model pengukuran pada Gambar 2 menunjukan bahwa ada satu indikator yang digunakan memiliki nilai loading factor $(\lambda)$ kurang dari 0,5 terlihat pada Gambar 2.

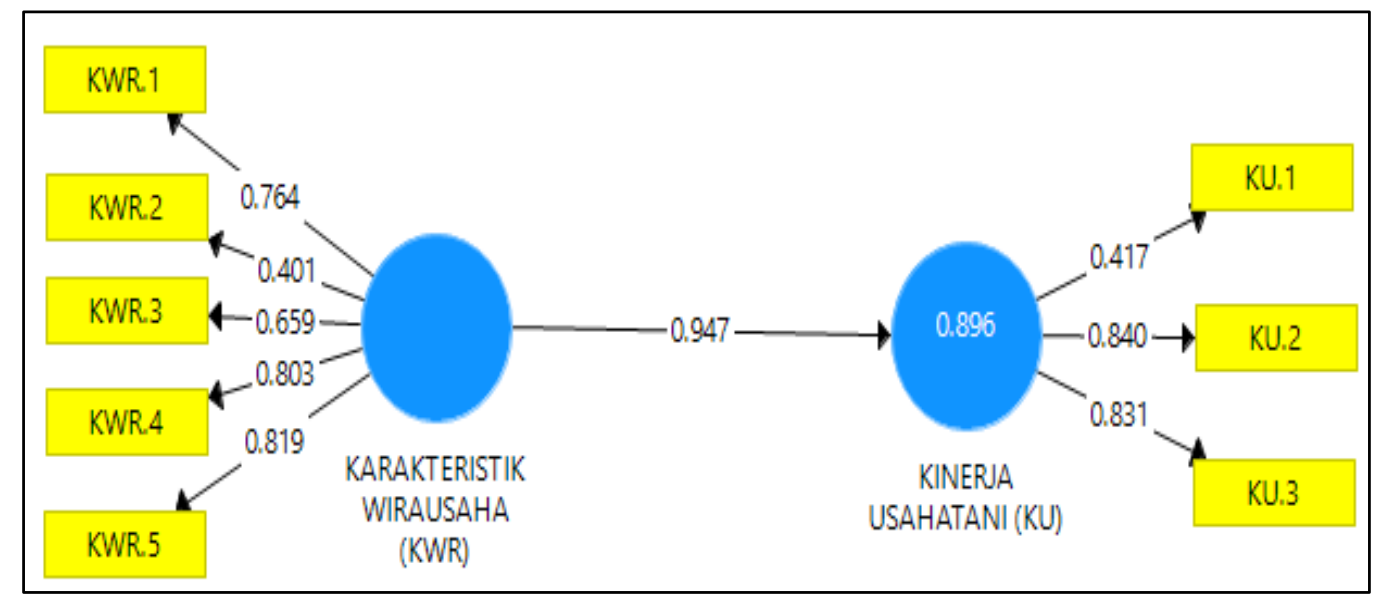

Gambar 2. Koefisen lintas model karakteristik wirausaha terhadap kinerja usahatani

Nilai AVE dan Composite Reliability yang diperoleh lebih dari 0,5 dan 0,7 . Artinya variabel yang digunakan, mempunyai reabilitas yang cukup baik, dapat dikatakan bahwa seluruh indikatorindikator yang digunakan benar-benar dapat dipercaya mengukur konstruknya. Nilai AVE dan Composite Reliability secara detail dapat dilihat pada Tabel 4. Hasil berdasarkan pengukuran evaluasi model pengukuran secara keseluruhan, yang terdiri dari uji validitas dan reliabilitas telah memuaskan. Hasil model final yang diperoleh dianggap baik dan dapat digunakan untuk pengujian hipotesis pada evaluasi model struktural selanjutnya. Evaluasi model setruktural pada tahap selanjutnya, dilakukan untuk menjelaskan korelasi dan signifikansi hubungan antar variabel konstruk. 
Tabel 4. Reabilitas model berdasarkan nilai AVE dan Composite Reability

\begin{tabular}{lccc}
\hline Variabel Laten & AVE & $\begin{array}{l}\text { Composite } \\
\text { Reliability }\end{array}$ & Keterangan \\
\hline $\begin{array}{l}\text { KARAKTERISTIK WIRAUSAHA } \\
\text { (KWR) }\end{array}$ & 0,795 & 0,854 & reliabel \\
KINERJA USAHATANI (KU) & 0,721 & 0,850 & reliabel \\
\hline
\end{tabular}

Evaluasi model struktural dapat dilakukan dengan melihat nilai R2 pada variabel endogen, dan nilai estimasi koefisien parameter jalur (Stone 1974 dan Giesser 1975 dalam Ghozali 2012). Evaluasi model struktural langkah pertama dilakukan untuk melihat nilai dari R-square (R2) dari model variabel laten endogen dalam penelitian. Menurut Latan dan Ghazali (2012) nilai R-square pada model, dapat dikategorikan kuat atau lemah. Model kuat jika memiliki nilai R-square 0,75 , sedangkan model lemah jika R-square 0,25. Latan dan Ghazali (2012), juga mengkategorikan model moderat, yaitu jika model memiliki nilai R-square 0,25 . Nilai R-square yang diperoleh dalam penelitian ini dapat dilihat pada tabel Tabel 5.

Tabel 5. Hasil uji statistik pengaruh karakteristik wirausaha usaha terhadap kinerja usaha

\begin{tabular}{ccc}
\hline Variabel Laten & R-Square & R Square Adjusted \\
\hline KINERJA USAHATANI (KU) & 0,902 & 0,901 \\
\hline
\end{tabular}

Penelitian ini bertujuan untuk melihat pengaruh karakteristik wirausaha terhadap kinerja usaha kopi arabika di Kabupaten Karo. Berdasarkan Tabel 5, dapat dilihat bahwa karakteristik wirausaha berpengaruh positif terhadap kinerja usahatani kopi

\section{Pengaruh Karakteristik Wirausaha Terhadap Kinerja Usahatani Kopi Arabika di Kabupaten Karo}

Penelitian ini bertujuan untuk melihat pengaruh karakteristik wirausaha terhadap kinerja usaha kopi arabika di Kabupaten Karo. Berdasarkan Tabel 6, dapat dilihat bahwa kinerja usahatani dipengaruhi positif dan signifikan oleh karakteristik wirausaha kopi arabika dengan nilai koefisien sebesar 0,961. Nilai 0,961 memberikan arti bahwa pengaruh arabika, dengan nilai koefisien sebesar 0,901 yang berarti pengaruh karakteristik wirausaha terhadap kinerja usahatani sebesar 90,1\%, sedangkan sisanya dijelaskan oleh variabel lain yang tidak digunakan dalam model.

karakteristik wirausaha terhadap kinerja usahatani sebesar 96,1\%. Nilai signifikansi pengaruh karateristik wirausaha terhadap kinerja usaha dianalisis berdasarkan hasil uji-t. Hasil yang diperoleh t-value > t-table yaitu 204,838 > 1.960, maka tolak H0 yang artinya karakteristik wirausaha berpengaruh signifikan terhadap kinerja usahatani kopi arabika di Kabupaten Karo. Hasil Uji statistik pengaruh karater wirausaha terhadap kinerja usahatani dapat dilihat pada Tabel 6.

Tabel 6. Nilai koefisien Jalur, Rataan, Simpangan baku, t-values

\begin{tabular}{lcccc}
\hline Variabel Laten & $\begin{array}{c}\text { Original } \\
\text { Sample }\end{array}$ & $\begin{array}{c}\text { Sample } \\
\text { Mean }\end{array}$ & $\begin{array}{c}\text { Standard } \\
\text { Deviation }\end{array}$ & T Statistics \\
\hline $\begin{array}{l}\text { KARAKTERISTIK WIRAUSAHA } \\
(\text { KWR })->\text { KINERJA USAHATANI }\end{array}$ & 0,961 & 0,921 & 0,050 & 204,838 \\
$(\mathrm{KU})$ & & & & \\
\hline
\end{tabular}

Hasil uji pengaruh karakteristik wirausaha terhadap kinerja usahatani memberikan pengaruh yang signifikan dengan koefisien yang positif. Artinya peningkatan karakteristik wirausaha menyebabkan kinerja usahatani meningkat. Hal tersebut menunjukkan pentingnya membangun karakteristik wirausaha karena karakteristik wirausaha tersebut sangat menentukan kinerja usahatani. Karakteristik wirausaha berpengaruh secara signifikan dan positif terhadap kinerja usaha dikarenakan dalam penerapannya karakteristik wirausaha sangat membantu dalam keberlangsungan usahatani kopi arabika. Burhanuddin et al (2018) mengatakan bahwa kunci sukses dalam pengembangan wirausaha petani yaitu kemampuan kewirausahaan (entrepreneurial skills) dan entrepreneur capacity.

Karakter pengambil risiko berpengaruh pada kinerja usahatani. Hal tersebut tercermin dari sebagian besar petani kopi berani dalam mengambil 
risiko harga jual kopi yang tidak stabil. Hal ini dikarenakan petani tidak mempunyai hak tawar. Harga kopi ditentukan oleh pedagang yang dengan mudah mengubah harga dalam hitungan jam, dimana harga kopi yang akan dijual pada pagi, siang dan malam hari tidak sama. Petani tidak berdaya terhadap perubahan harga tersebut.

\section{Dimensi Karakteristik Wirausaha}

Karakteristik wirausaha dicerminkan oleh lima indikator yakni pengalaman, pendidikan, persepsi terhadap usahatani, motivasi berprestasi dan keinginan berusahatani. Hasil olah data dengan menggunakan SEM-PLS menunjukkan bahwa dari empat indikator tersebut terdapat satu indikator yaitu pendidikan tidak signifikan membentuk dimensi karakteristik wirausaha. Variable lain sebanyak empat indikator mampu menunjukkan bahwa karakteristik wirausaha, dibuktikan berdasarkan pada nilai koefisien atau dari nilai loading factor bernilai positif dengan nilai lebih dari 0,5 serta memiliki nilai t-value lebih besar dari t-table $(1,960)$ pada Tabel 7 .

Tabel 7. Koefisien pengaruh dan signifikansi variabel karakteristik wirausaha

\begin{tabular}{|c|c|l|r|r|c|}
\hline No & Simbol & \multicolumn{1}{|c|}{ Indikator } & $\begin{array}{c}\text { Loading } \\
\text { Factor }\end{array}$ & t-value & Keterangan \\
\hline 1. & KWR.1 & Pengalaman & 0,764 & 17,252 & Signifikan \\
\hline 2. & KWR.3 & Persepsi terhadap usahatani & 0,659 & 10,457 & Signifikan \\
\hline 3. & KWR.4 & Keberanian mengambil risiko & 0,803 & 22,501 & Signifikan \\
\hline 4. & KWR.5 & Keinginan Berusahatani & 0,819 & 34,205 & Signifikan \\
\hline
\end{tabular}

Menurut Meredith et al (2000) ke empat karakteristik wirausaha tersebut merupakan karakter (psikologis) yang seyogyanya dimiliki dan perlu dikembangkan untuk menjadi seorang wirausaha yang sukses. Berdasarkan data pada Tabel 6, indikator utama di dalam karakteristik wirausaha adalah karakter keorisinilan dengan nilai koefisien 0,819 dan memiliki nilai t-value sebesar 34,205. Keinginan berusahatani menjadi indikator utama yang memberikan kontribusi terhadap karakteristik wirausaha, petani mempunyai keinginan yang besar untuk mempertahankan usahatani kopi arabika, sebagai usaha sampingan. Petani yang menjalankan usahatani kopi ini tidak berkeinginan untuk pindah usaha karena menurut petani usaha yang dijalankannya mempunyai prospek yang cerah kedepannya dan sebagai investasi bagi keluarganya.

$$
\text { Keadaan dilapangan menunjukkan }
$$

keberagaman tingkat pendidikan petani, meskipun demikian pengalaman dan keinginan berusaha yang dimiliki petani dapat meningkatkan motivasi, meningkatkan kemampuan menghadapi risiko untuk terus meningkatkan kinerja usahatani. Melalui pengalaman dalam berusahatani petani kopi dapat mencari cara yang lebih baik untuk menjalankan dan mengatur usaha mereka. Dengan adanya keinginan untuk terus berusaha petani harus terus mencari informasi tentang bibit unggul, manajemen budidaya kopi yang benar akan mampu untuk meningkatkan keuntungan dan produktifitas kopi mereka.

\section{Dimensi Kinerja Usahatani}

Kinerja usahatani dicerminkan oleh empat indikator yakni peningkatan pendapatan, peningkatan jumlah tenaga kerja, peningkatan volume penjualan dan perluasan wilayah pasar. Hasil olah data pada Tabel 8, menggunakan metode PLS menunjukkan bahwa ke empat indikator berpengaruh dan berkontribusi positif terhadap kinerja usaha. Semua indikator tersebut memiliki hubungan positif dan pengaruh yang signifikan, dibuktikan dengan nilai koefisien atau outer factor yang bernilai positif dengan nilai lebih dari 0,70 serta memiliki nilai tvalue lebih besar dari t-table $(1,960)$.

Tabel 8. Koefisien pengaruh dan signifikansi variabel kinerja usahatani

\begin{tabular}{|c|c|l|c|c|c|}
\hline No & Simbol & Indikator & Loading Factor & t-value & Keterangan \\
\hline 1. & KU.2 & Pendapatan & 0,804 & 28,792 & Signifikan \\
\hline 2. & KU.3 & Komitmen berusahatani & 0,831 & 43,681 & Signifikan \\
\hline
\end{tabular}

Tabel 8, tingkat pendapatan merupakan adanya peningkatan pendapatan yang diterima oleh petani dari periode sebelumnya. Hasil wawancara dengan petani kopi di Kabupaten Karo bahwa berusahatani kopi ini sebagian kebutuhan hidup sudah terpenuhi dan petani juga mengatakan bahwa beban hutang yang dimiliki juga berkurang. selain itu, pendapatan yang diperoleh petani dari hasil penjualan kopi digunakan untuk modal berikutnya, perbaikan rumah dan untuk pendidikan anak mereka.

Keunggulan bersaing memiliki arti bahwa mampu untuk menciptakan keunggulan produk untuk bisa bersaing dengan produk lainnya. Hasil penelitian menunjukan produksi kopi petani satu petani dengan 
petani yang lain bisa dapat berbeda. Petani di Kabupaten Karo selalu melakukan mengontrol tanaman kopi setiap harinya, hal dikarenakan untuk mengecek kondisi tanaman. Jika ingin menjual kopi dengan harga tinggi, maka petani harus

\section{KESIMPULAN}

Karakteristik kewirausahaan petani kopi arabika di Kabupaten Karo yaitu pengalaman yang cukup, persepsi terhadap usahatani yang tergolong cukup, keberanian mengambil risiko terutama risiko harga jual kopi yang tidak stabil dan keinginan Berusahatani yang tinggi. karakteristik wirausaha berpengaruh positif terhadap kinerja usahatani. Hal ini dilihat dari pendapatan yang diperoleh oleh petani kopi dari hasil usahanya. Pendapatan yang diperoleh petani kopi rata-rata Rp 2.100.000-Rp 3.000.000

\section{DAFTAR PUSTAKA}

AEKI. (2019). Luas areal dan Produksi Kopi

[Internet]. [diunduh 2019 Mei 10]. Tersedia pada:

http://www.aekiaice.org/page/areal-danproduksi/id.

AEKI. (2019). Ekspor Kopi. Dalam http://www.aekiaice.org/coffee_export_reg ulations.html diakses pada tanggal 29 Juni 2019 pukul 15.00 WIB.

Ghozali, Imam. (2008). Aplikasi Analisis Multivariate dengan Program SPSS.

Semarang: Badan Penerbit Universitas Diponegoro

Ghozali, Imam. (2012). Aplikasi Analisis Multivariate dengan Program IBM SPSS. Yogyakarta: Universitas Diponegoro

ICO. (2019). "Data Konsumsi Kopi". diakses 12 Agustus 2019. http://www.ico.org/new_historical.asp

Latan, H. Ghazoli. (2012). Partial Least Square : Konsep, Teknik dan Aplikasi SmartPLS 2.0 M3. Semarang: Badan Penerbit Universitas Diponegoro.

Kanaka,S., Chinnadurai,M. (2015). The Policy Analysis Matrix Of Rice Cultivation In India. European Journal OfBasic And Applied Sciences. 2(1):32-45.

Welter, F \& Smallbone, D. (2011). 'Institutional perspectives on enterpreneural behavior in challenging environments'. Journal of Small Busines Management, Manajemen, Universitas Diponegoro, Semarang, vol. 49, no. 1 , pp. 107-125. meningkatkan kualitas biji kopi yang dihasilkan melalui pemilihan bibit kopi yang baik sesuai dengan standar mutu nasional. Lalu memberikan pupuk sesuai dengan kebutuhan tanaman, membersihkan pohon kopi dari hama pengganggu.

permusim panen. Karakteristik wirausaha sangat penting dibangun, karena karakteristik wirausaha akan menentukan keberhasilan dalam menjalankan usaha kedepannya.

\section{UCAPAN TERIMA KASIH}

Terima kasih penulis ucapkan atas bantuan dana Riset yang dibiayai oleh Hibah Penelitian Dosen Pemula dari DRPM Ristek Dikti dengan surat keputusan nomor T/140/E3/RA.00/2019 dan perjanjian/Kontrak Nomor T/49/L1.3/PT.01.03/2019.

Martauli,ED. (2018). Analisis Produksi Kopi di Indonesia. Journal Of Agribusiness Scienes. 1(2);112-120

Meiri Angga, Nurmalina Rita. (2013). Analisis Perdangan Kopi Indonesia di Pasar Internasional. Jurnal Tanaman Industri dan Penyegar, 2:39-46.

Meredith, G.G. (2000). Kewirausahaan: Teori dan Praktik. Jakarta: Pustaka

Minniti M, Bygrave W. (2001). A Dynamic Model of Entrepreneurial Learning. Entrepreneurship Theory and Practice. United Stated [US]: Spring.

Pambudy R. (2010). Membangun Entrepreneur Agribisnis yang Berdaya Saing, Orange Book 2 Bogor (ID): IPB Press.

Purnami, Adnyana. (2016). Pengaruh Pendidikan Kewirausahaan, Self Efficacy Dan Locus Of Control Pada Niat Berwirausaha. EJurnal Manajemen Unud, Vol. 5, No. 2, 2016: 1160-1188 ISSN: 2302-8912

Puspitasari, Nurmalina R, Fariyanti A, Kiloes AM. (2013). Pengaruh Faktor Internal dan Eksternal Terhadap Perilaku Kewirausahaan dan Dampaknya Terhadap Kinerja Usaha Petani Anggrek. J. Hort. 28(2): 299-310 